C JBSSR/AIM, 2018, ISSN: 2542-2812.

\title{
A Sectoral Analysis of Foreign Direct Investment on the Economic Growth of Nepal
}

\author{
Ram Kumar Phuyal ${ }^{1}$ and Seema Sunuwar ${ }^{2}$
}

\begin{abstract}
The role of foreign direct investment (FDI) on the economic growth is widely concerned in terms of increase in employment opportunities and for overall economic welfare, especially in developing nations like Nepal. On this context, this paper makes an attempt to examine the sector wise effects of FDI on economic growth in Nepal represented by gross domestic product (GDP) and FDI as dependent and independent variables respectively, thereby identifying the direct effect of FDI on GDP using 10 years (2007 to 2016) sectoral data as main source of the information. The entire result of the inferential analysis predicts that FDI of industry, tourism and agriculture sectors have a very positive and significant impact on GDP during the stipulated timeframe. In this line, findings suggest that the main stakeholders and government have to come up with new policy to open up foreign investment in other sectors as well which helps to move informal activities into formal economy. Finally, it is noted that formulation of new plan and policy will be a necessary condition but not sufficient step for the development, so the key recommendations are made for the effective steps and actions to be taken by the concerned authority to review and implement the introduced plan and policies, which in turn, will help in flow of FDI to achieve, accelerate, and sustain the high rate of economic growth in Nepal.
\end{abstract}

Keywords: economic growth, GDP, FDI, Nepal

\section{Introduction}

One of the main reason behind Singapore becoming an economic success was, lots of foreign trade helped transform this tiny state into a regional powerhouse (The Economist, 2015). This is just an example of the power of the free flow of capital and the extent of openness of the overall market for success of any economy. FDI is one of the most significant factors of economic growth, which encourages productivity of the national economy, augments the use of technology, reducing unemployment by creating new jobs and other encouraging output that differentiate

1 Dr. Phuyal is Associate Professor of Economics, CEDA, Tribhuvan University. Corresponding Email: phuyal_ram5@yahoo.com

2 Ms Sunuwar is the faculty of Nepal college of Management, Affiliated to Kathmandu University. 
this form of investment from other funding sources (Al-Eitan, 2013). It has been considered as a growth enhancing factor in the developing and developed countries alike (Te Velde, 2006). Any investment that flows from one country into another is known as foreign investment. Inflow of investment from other countries is encouraged since it complements and stimulates domestic investments in capitalscarce economies of developing countries (Cristina \& Levieuge, 2013).

The journey of foreign investment in Nepal began with the proclamation of the Nepal Foreign Investment and Technology Transfer Act (NFITTA) in 1992 (NFITTA, 1992). Currently, Nepal's foreign investment rules and regulations have been formulated on the basis of the FITTA 1992 which was revised in 1996 in line with open and liberal economic policies (Ghimire, 2012).FITTA 1992 defines that foreign investment means the following investment made by a foreign investor in any industry: a) investment in share (equity); b) re-investment of the earnings derived from the investment in share (equity); and c) investment made in the form of loan or loan facilities. The minimum investment needs to be equivalent to US\$ 20,000 (NFITTA, 1992).

FDI inflows into Nepal had a relatively constant trend after the financial liberalization (Adhikari, 2013), but a significant rise in investment was marked only after the conflict period of 2002 till 2007. Although the government has tried to make an effort to uplift FDI flows in the country, they have not had any remarkable impact so far. With the increasing liberalization throughout the world, globalization has set its foot everywhere and developing countries are also not immune from this effect (Stallings, 2001). This has led to more difficulty for Nepal to attract new investment flows since there is immense competition for FDI among developing countries (Adhikari, 2013). Hence, attracting and retaining FDI on a sustainable basis is a major development challenge for Nepal (Pant, 2010).

FDI has been recognized as growth enhancing factor in most of the developing countries (Hoang et al., 2010). Nepal being one of the least developed countries in the world, with about one-quarter of its population living below the poverty line (Ranjit, 2016) definitely needs FDI as the growth enhancing factor. Agriculture is the mainstay of the economy, providing a livelihood for three-fourths of the population and accounting for a little over one-third of the gross domestic product (GDP) which is one of the primary indicators used to gauge the health of a country's economy (Shrestha, 2003). GDP represents the total dollar value of all goods and services produced over a specific time period; we can think of it as the size of the economy (Wolla, 2013).

Despite abundant natural and human resources, Nepal is poor, and the agrarian economy contributes low per capita income and productivity of the economic 
resources (Basnett et al., 2014). The GDP growth rate of Nepal has never been consistent since the last few decades. Nepal secured highest growth of 8.2 percent in 1994 and lowest growth of 0.12 percent in 2002 (Acharya, 2013). Nepal is one of the liberalized countries in the South Asian region. However, the growth performance has been very poor in recent years. In this context, a closer examination of the linkages between foreign direct investment and economic development is critically important from a policy point of view (Kundan \& Gu, 2010).

In Nepal, it is felt that the flow of FDI is still quite low in comparison to other developing countries given the huge potential of adjoining markets, favorable climate, cheap labor, vast natural resources; etc. which has direct impact on Nepal's economy (Bhattarai, 2009). In case of Nepal, only few studies have been carried out to ascertain the FDI-economic growth nexus whereas no such studies have been done regarding the effect of sector wise FDI flow to GDP. Under the prevalence of these situations, the study has tried to attempt to answer the question: Is there any significant relationship between FDI in different sectors and economic growth contributed by those sectors?

In the previous studies made about the Economic Growth in Nepal, mainly the trends, problems and prospects are focused. Very few studies have been made regarding the relationship of sector wise FDI and economic growth of Nepal. This study is important to know how well the FDI flow and practices are catering the needs of economic growth in Nepal. It is important for the investors and government to take various decisions. The study is important for the interested enthusiast to know more about the area. It may encourage other researchers to research further. Therefore, the basis of the study is apparent.

\section{The Literature Review}

The impact of FDI on economic growth remains far from conclusive in empirical studies with mix results. While some studies observe a positive impact of FDI in economic growth, other detects a negative relationship between these two variables. Many studies suggest that the significant positive effects, while some studies find no independent effect of FDI on host country economic growth. Moreover, the existing studies have mostly focused on explore impact of inward FDI on host country economic growth. For example De Mello (1999) suggested that whether FDI contributes to the economic growth depends on quantum of skilled labor in host country. Alfaro (2003) found that total FDI has an ambiguous effect on host country economic growth; FDI inflows into primary sector tend to have negative effect on growth, manufacturing sector has positive spillover.

When FDI and economic growth showed positive relationship, the impact was dependent on the human capital in the host economy as found by Borenzstein et al. 
(1998).The level of development of local financial markets is crucial for these positive effects to be realized. Better local conditions not only attract foreign companies but also allow host economies to maximize the benefits of foreign investments. However for FDI to contribute to economic growth, the host country must have achieved a minimum threshold level of development in education, technology, infrastructure, financial markets, and health. Thus, FDI contributes to economic growth only when the host country has reached a developmental level capable of absorbing the advanced technology that it brings.

An empirical analysis using cross-country data for the period of 1981-1999 showed that investment made in manufacturing sector showed a fruitful outcome (Alfaro 2003).According to Blomström and Kokko (2003), the contributions of FDI to the development of a country are widely recognized as filling the gap between desired investments and domestically mobilized saving, increasing tax revenues, and improving management and technology, as well as labor skills in host countries. These could help the country to fight its way out of poverty.

Nonnemberg and De Mendonça (2004) showed that FDI is correlated to level of schooling, economy's degree of openness, risk and variables related to macroeconomic performance like inflation, risk and average rate of economic growth. The results also show that the FDI has been closely associated with stock market performance. A causality test between FDI and GDP showed existence of causality in sense that GDP leading to FDI, but not vice versa.

Economic growth increases the market size of the host country market and strengthens the incentives for market seeking FDI resulting in a situation where FDI and economic growth are mutually supporting (Johnson, 2006). FDI inflows are a source of technological progress and increasing employment in most developing countries, which increases the production of goods and services and, ultimately, increases GDP. In order to enhance economic growth, policies should device to attract export oriented FDI instead of domestic demand oriented (Iram \& Nishat, 2009).The study by Hoang, Wiboonchutikula and Tubtimtong showed that there is a strong impact of FDI on economic growth in Vietnam. Even though there is a "market stealing" effect on the domestic investment, FDI inflow does exert an independent influence on Vietnamese economic growth. Carp (2012) found that the impact capital flows exert on host country is significant and the main channels through which the effects are transmitted are: financial markets, host country absorptive capacity, human capital and technological.

A study made by Majagaiya (2010) on "A Time Series Analysis of Foreign Direct Investment and Economic Growth: A Case Study of Nepal" concluded that Nepal's Gross Domestic Product growth rate especially does not depend upon FDI. Abbas et al. (2011) in their study "Impact of Foreign Direct Investment on Gross 
Domestic Product" investigated the impact of foreign direct investment on Growth (GDP) of SAARC countries. The result shows that there is a positive and significant relationship between GDP and FDI while an insignificant relationship between GDP and inflation.

Aizhan and Makaevna (2011) explored the "Impact of Foreign Direct Investment on Economic Growth in Kazakhstan" to show role played by FDI in Kazakhstan economic growth and its future prospects. Within the Central Asia and CIS countries Kazakhstan is one of the rapidly growing and one of the most FDI attractive countries which attracted 58 percent of all FDI to land-locked developing countries in 2009. According to UNCTAD, Kazakhstan is FDI attractive, at the same time it has highly dependence on energy sector. Being highly dependent on energy sector can bring negative impact on economy of Kazakhstan. They suggested that it could be better to direct FDI to other sectors to assure long time growth.

\section{The Methodology}

\subsection{Conceptual Theory}

Dependent and independent variables are identified and different analysis are performed to determine their relationships. Industrial Enterprises Act (1992) has classified Industries under (i) Agro and Forest - based Industries (ii) Construction Industries (iii) Energy-based Industries (iv) Manufacturing Industries (v) Mineral Industries (vi) Service Industries and (vii) Tourism Industries.

Agro and Forest - based Industries cover those businesses mainly based on agriculture or forest products such as integrated sericulture and silk production, horticulture and fruit processing, animal husbandry, dairy industry, poultry farming, fishery, tea gardening and processing, coffee farming and processing, herb culture and herb processing, vegetable seed farming; bee-keeping, honey production, rubber farming, floriculture and production, and forestry related businesses such as lease-hold forests, agro-forestry etc. Mushroom, vegetable farming or vegetable processing, tissue-culture, green house, cotton farming, production and processing of cotton seeds, horticulture and cash crop farming; Cane and bamboo farming \& their products; Hatchery; Establishment, protection and management of botanical garden.

Construction Industries cover those industries which construct road, bridge, ropeway, railway, trolley bus, tunnel, flying bridge and industrial, commercial and residential complex construction and operation, office and residential complex construction and operation, sports complex, swimming pool, airport, film studio construction and operation. Infrastructure building of auditorium and conference hall; drainage system; water supply system (pipelining), fuel and gas supply system (pipelining); irrigation system, energy house (power house) and energy distribution system (transmission line) and operation and management thereof. 
Energy-based Industries cover industries generating energy from water resources, wind, solar, coal, natural oil and gas, biogas or any other sources.

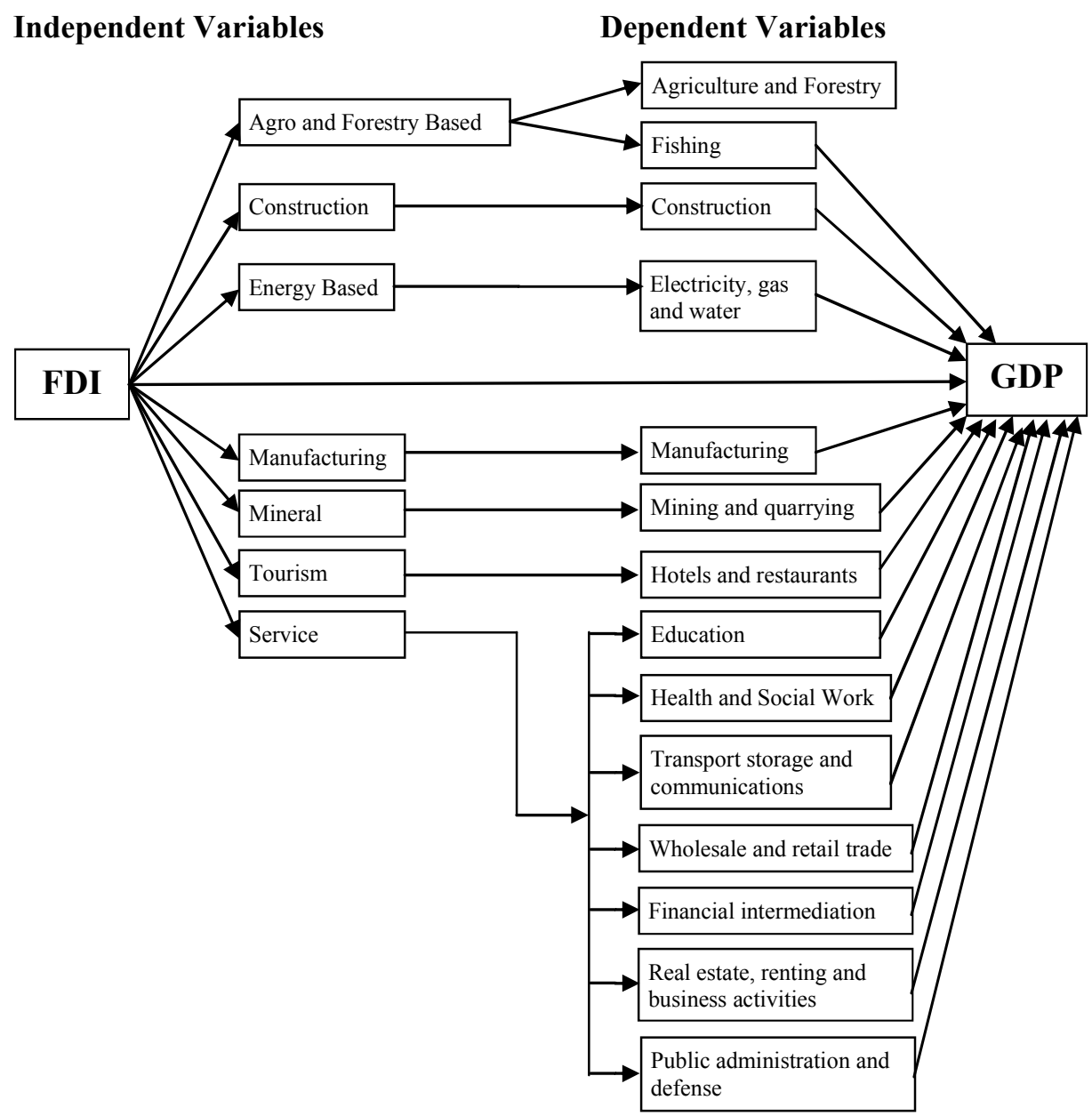

Figure 1: Conceptual framework

Manufacturing Industries cover those industries which produce goods by utilizing or processing raw materials, semi-processed materials, by-products or waste products or any other goods, production and packing of photographic film roll by cutting, slitting, confecting, perforating, spooling and capping from Jumbo roll; production of cinematographic film, medical and industrial x-ray film, graphic art film, photographic paper by cutting, slitting process from imported Jumbo role and pan cake industry. 
Mineral Industries cover mineral excavation or processing thereof.

Service Industries cover workshop, printing press, consultancy service, ginning and bailing business, cinematography, construction business, public transportation business, photography, hospital, nursing home, educational and training institution, laboratory, air services, cold storage, production (having less processing activities) of cut to length sheet, photo film slitting, photo paper slitting, tissue paper slitting, ball bearing assembly; repacking of imported goods in bulk quantity. It also includes housing complex business; telephone service (cellular telephone, mobile telephone, pager service), television broadcasting (satellite television and cable television); textile \& yarn dying, yarn sizing and textile printing (except for textile knitting industries using for their own product), development of computer software, public transport (three or four wheelers) operated by electricity or battery; battery charging for those electrical vehicles, security service business providing security to bank and financial institutions, industry, hotel, office complex, diplomatic institutions and residential complex.; advertising agency; publications house ; L P gas refilling for domestic use; mapping business by digitations process (digital mapping services); production of teledrama, tele-film advertisement, health education programme and other documentary films broadcasting on television; L.P.gas refilling depot on vehicles (motorcar and tempo); construction of radio station and broadcasting service, cargo business, public carrier transport service, shipping business; packaging and refilling; courier, telephone system; dry-cleaners; catering; video- audio recording; v-sat; internet; beauty parlour; milling, grinding and extracting of grain on commercial basis; interior decoration; CD Rom recording, operation and management of inland clearance depot, renting, repairing and operating service of construction heavy equipment; veterinary medical service; diagnostic services to human health (Clinic); operation of conference \& auditorium hall, drainage and wastage/garbage collection and processing thereof, water supply, pipelining of fuel, fuel related gas supply, warehousing and storage, airport, sports complex, rope way, road, irrigation, energy house, railway and maintenance and transportation service by animal.

Tourism Industries cover tourist lodging, motel, hotel, restaurant, resort, travel agency, skiing, gliding, water rafting, cable car complex, pony-trekking, trekking, hot air ballooning, Para sailing, golf-course, polo, horse-riding; construction \& operation of amusement park; rural tourism and other adventurous tourism.

\section{Data Analysis and Results Discussion}

\section{The Data}

To achieve the objectives of the study, analytical research design has been used so that logical conclusion could be drawn. This study is based on secondary data collected from the annual report of MOF, CBS and DOI. Based on these data, the main objective 
of this research study is an attempt to draw logical conclusion that whether there exists relationship of FDI with GDP for which regression analysis has been used to draw necessary conclusion. This study focused on effects of FDI, ER and IR on GDP. Thus, the study used annual data of FDI flow, GDP, ER and IR from fiscal year1993/94 to 2014/15. This study also covers sector wise FDI and GDP data from 1993/94 to $2014 / 15$ as the sample of the study. Since the nature of the data is secondary, it is based on published reports, journals and previously conducted research papers. Basically the following data are useful for the research study (i) Annual Sector wise GDP at Current Price and (ii) Annual Sector Wise FDI Inflow Amount.

Economic activities are divided into 15 sectors namely Agriculture Forestry and Logging; Fishing; Mining and Quarrying; Manufacturing; Electricity Gas and Water; Construction; Hotels and Restaurants; Transport Storage and Communication; Financial Intermediation; Trade; Real Estate Renting and Business Activities; Public Administration and Defense; Education; Health and Social Work; Other community, social and personal service whereas FDI flow into Nepal is divided into 7 sectors namely Manufacturing, Service, Tourism, Construction, Energy based, Agro and forest based and Minerals. In order to match all the seven sectors of FDI with GDP, some similar economic activities are merged into one like (Agriculture Forestry and Logging; Fishing) into Agro and forest based industry and (Trade; Real Estate Renting and Business Activities; Public Administration and Defense; Education; Health and Social Work; other community, social and personal service) into Service industry. An attempt has been made to collect data from reliable source i.e. published annual report of MOF, CBS and DOI for accuracy. The reliability and validity of the secondary data have been assured through the use of official websites and published reports.

\section{The Model}

In this study, linear regression analysis is used to investigate relationship between the dependent and independent variables. The following panel data equation is used to evaluate empirically the effect of FDI on economic growth in Nepal. The regression model tests the relationship between the different sectors of economy of Nepal with different sectors of FDI. The given model depicts GDP as dependent variable; whereas independent variables is FDI as specified as:

Ln (GDP Agriculture $)=\beta_{0}+\beta_{1} \operatorname{Ln}($ FDI Agriculture $)+e$

$\operatorname{Ln}($ GDP Construction $)=\beta_{0}+\beta_{1} \operatorname{Ln}($ FDI Construction $)+e$

Ln (GDP Energy) $=\beta_{0}+\beta_{1} \operatorname{Ln}($ FDI Energy) $+\mathrm{e}$.

Ln (GDP Manufacturing) $=\beta_{0}+\beta_{1} \operatorname{Ln}$ (FDI Manufacturing) $+\mathrm{e}$

$\operatorname{Ln}($ GDP Mineral $)=\beta_{0}+\beta_{1} \operatorname{Ln}($ FDI Mining $)+e$

$\operatorname{Ln}($ GDP Tourism $)=\beta_{0}+\beta_{1} \operatorname{Ln}($ FDI Tourism $)+e$

$\operatorname{Ln}($ GDP Service $)=\beta_{0}+\beta_{1} \operatorname{Ln}($ FDI Service $)+e$ 
Here, LnGDP Agriculture; LnGDP Construction; LnGDP Energy; LnGDP Manufacturing; LnGDP Mineral; LnGDP Tourism and LnGDP Service are dependent variables. Similatly, LnFDI Agriculture; LnFDI Construction; LnFDI Energy; LnFDI Manufacturing; LnFDI Mineral; LnFDI Tourism and LnFDI Service are corresponding independent variables. Here $\beta$ represent intercept, $\beta_{\mathrm{i}}$ shows coefficient of the $\mathrm{i}^{\mathrm{t}}$ independent variable and $\mathrm{e}$ is random error.

\subsection{Correlation Analysis}

Correlation is applied to study the statistical relationship of the GDP with FDI. The following table presents the output, when correlation is run to the 10 years data considered. Table 1 shows the correlation between sector wise GDP and FDI. Energy, Agriculture, and Service sectors are found to have positive correlation and significant relation with FDI; Tourism and Manufacturing sectors have positive correlation but insignificant relationship with FDI while Construction and Mining sectors have negative correlation and insignificant relation with FDI.

Table 1: Correlation Matrix of sector wise GDP and its Determinant

\begin{tabular}{llll}
\hline Dependent Variables & & & Independent Variables \\
\hline \multirow{4}{*}{ GDP_Agriculture } & Pearson Correlation & $.678^{*}$ & \\
& Sig. (2-tailed) & 0.031 & FDI_Agriculture \\
& $\mathrm{N}$ & 10 & \\
GDP_Construction & Pearson Correlation & -0.006 & \\
& Sig. (2-tailed) & 0.986 & FDI_Construction \\
& $\mathrm{N}$ & 10 & \\
GDP_Energy & Pearson Correlation & $.712^{*}$ & \\
& Sig. (2-tailed) & 0.021 & FDI_Energy \\
& $\mathrm{N}$ & 10 & \\
GDP_Manufacturing & Pearson Correlation & 0.552 & \\
& Sig. (2-tailed) & 0.098 & FDI_Manufacturing \\
& $\mathrm{N}$ & 10 & \\
GDP_Mining & Pearson Correlation & -0.154 & \\
& Sig. (2-tailed) & 0.671 & FDI_Mining \\
& $\mathrm{N}$ & 10 & \\
GDP_Service & Pearson Correlation & $.646^{*}$ & \\
& Sig. (2-tailed) & 0.044 & FDI_Service \\
& $\mathrm{N}$ & 10 & \\
GDP_Tourism & Pearson Correlation & 0.606 & \\
& Sig. (2-tailed) & 0.063 & FDI_Tourism \\
\hline .* Significan & $\mathrm{N}$ & 10 & \\
\hline
\end{tabular}

** Significant at the 0.01 level (2-tailed) and * Significant at the 0.05 level (2-tailed). 


\subsection{Regression Analysis}

In order to examine the effects of FDI and other macro-economic variables on GDP, the Test of normality and regression analysis are carried out. In time series data, we must ensure that the data must be normal. Before running regression analysis, normality of data must be checked to ensure the normality in the time series data. Hence we perform Shapiro-Wilk test to ascertain the normality of data sets. After log transformation, the data are normalized and ready for the further research. From the Shapiro-Wilk test, we can see that all of the p-values are more than 0.05 which indicates that the data set is normal except for GDP Energy. Hence, energy sector is not considered since it failed the normality test.

Table 2: Normality Test

\begin{tabular}{llll}
\hline Shapiro-Wilk & & & \\
\hline Variables & Statistic & df & Sig. \\
\hline Ln_GDPAgro and forest based & 0.942 & 7 & 0.657 \\
Ln_GDPConstruction & 0.944 & 7 & 0.673 \\
Ln_GDPEnergy & 0.801 & 7 & 0.042 \\
Ln_GDPManufacturing & 0.928 & 7 & 0.533 \\
Ln_GDPMinerals & 0.921 & 7 & 0.478 \\
Ln_GDPService & 0.947 & 7 & 0.704 \\
Ln_GDPTourism & 0.937 & 7 & 0.611 \\
Ln_FDIAgro and forest based & 0.949 & 7 & 0.716 \\
Ln_FDIConstruction & 0.9 & 7 & 0.333 \\
Ln_FDIEnergy & 0.898 & 7 & 0.32 \\
Ln_FDIManufacturing & 0.926 & 7 & 0.518 \\
Ln_FDIMining & 0.945 & 7 & 0.684 \\
Ln_FDIService & 0.875 & 7 & 0.205 \\
Ln_FDITourism & 0.893 & 7 & 0.292 \\
\hline
\end{tabular}

Table 3 is the model summary which reports the strength of the relationship between the model and the dependent variable GDP. R, the simple correlation coefficient, is the linear correlation between the observed and model predicted values of the dependent variable. Its large value indicates a strong relationship. $\mathrm{R}$ Square, the coefficient of determination, is the squared value of the multiple correlation coefficients. From the table, we can see there is a higher degree of correlation between FDI and GDP of Service sector, moderate correlation of Agro $\&$ Forest based, Manufacturing and Tourism whereas lower correlation of Construction and Minerals sector. The $R^{2}$ value indicates how much of the total variation in the dependent variable (GDP), can be explained by the independent variable (FDI). In case of Agro \& Forest based (41\%), Construction (5\%), Manufacturing (43\%), Mineral (12\%), Service (70\%) and Tourism (41\%) variation can be explained. 
Table 3: Model Summary

\begin{tabular}{lllll}
\hline Sector & R & R Square & Adjusted R Square & Std. Error \\
\hline Agro and forest based & $.640 \mathrm{a}$ & 0.41 & 0.326 & 0.27372 \\
Construction & $.232 \mathrm{a}$ & 0.054 & -0.104 & 0.44952 \\
Manufacturing & $.661 \mathrm{a}$ & 0.437 & 0.366 & 0.23962 \\
Minerals & $.355 \mathrm{a}$ & 0.126 & 0.016 & 0.44025 \\
Service & $.842 \mathrm{a}$ & 0.709 & 0.673 & 0.22764 \\
Tourism & $.641 \mathrm{a}$ & 0.411 & 0.337 & 0.42697 \\
\hline
\end{tabular}

Agro and Forest Based Sector: The positive sign of beta coefficient signifies a direct relationship between the explained (GDP Agro and forest based sector) and explanatory variables (FDI Agro and forest based sector) that shows FDI Agro and forest based sector $(0.127)$ has positive insignificant impact on economic growth, since; $p$-value is more than 0.05. Construction Sector: The positive sign of beta coefficient signifies a direct relationship between the explained (GDP Construction) and explanatory variables (FDI Construction). It means, FDI Construction (0.063) has positive insignificant impact on economic growth, since; p-value is more than 0.05.Manufacturing Sector: We can observe that the beta for FDI Manufacturing is 0.141 .The positive sign of beta coefficient signifies a direct relationship between the explained (GDP Manufacturing) and explanatory variables (FDI Manufacturing). Hence, FDI Manufacturing (0.141) has positive significant impact on economic growth, since; $p$-value is less than 0.05 .

Minerals Sector: From table 4, we can observe that the beta for FDI Minerals is 0.111 . The positive sign of beta coefficient signifies a direct relationship between the explained (GDP Minerals) and explanatory variables (FDI Minerals). FDI Minerals (0.111) has positive insignificant impact on economic growth, since; pvalue is more than 0.05 . Service Sector: We can observe that the beta for FDI Service is 0.25 .The positive sign of beta coefficient signifies a direct relationship between the explained (GDP Service) and explanatory variables (FDI Service).FDI Service (0.25) has positive significant impact on economic growth, since; $p$-value is less than 0.05. Tourism Sector: From table 4, we can observe that the beta for FDI Tourism is 0.282 . The positive sign of beta coefficient signifies a direct relationship between the explained (GDP Tourism) and explanatory variables (FDI Tourism). FDI Tourism (0.282) has positive significant impact on economic growth, since; $\mathrm{p}$-value is less than 0.05 . 
Table 4: Test Statistics on Linear Regression for sector wise GDP contributed by FDI of different sectors

\begin{tabular}{|c|c|c|c|c|c|}
\hline \multirow[t]{2}{*}{ Variables } & \multicolumn{2}{|c|}{ Unstandardized Coefficients } & \multirow{2}{*}{$\begin{array}{l}\text { Standardized Coefficients } \\
\text { Beta }\end{array}$} & \multirow[t]{2}{*}{$\mathrm{T}$} & \multirow[t]{2}{*}{ Sig. } \\
\hline & B & Std. Error & & & \\
\hline Ln_FDIAgro & $\begin{array}{l}0.127 \\
(12.319)\end{array}$ & $\begin{array}{l}0.058 \\
(0.341)\end{array}$ & 0.64 & $\begin{array}{l}2.206 \\
(36.158)\end{array}$ & 0.063 \\
\hline Ln_FDICons & $\begin{array}{l}0.063 \\
(11.023)\end{array}$ & $\begin{array}{l}0.107 \\
(0.552)\end{array}$ & 0.232 & $\begin{array}{l}0.584 \\
(19.956)\end{array}$ & 0.581 \\
\hline Ln_FDIManu & $\begin{array}{l}0.141 \\
(10.179)\end{array}$ & $\begin{array}{l}0.057 \\
(0.468)\end{array}$ & 0.661 & $\begin{array}{l}2.491 \\
(21.757)\end{array}$ & 0.037 \\
\hline Ln_FDIMining & $\begin{array}{l}0.111 \\
(8.296)\end{array}$ & $\begin{array}{l}0.103 \\
(0.568)\end{array}$ & 0.355 & $\begin{array}{l}1.073 \\
(14.616)\end{array}$ & 0.315 \\
\hline Ln_FDIService & $\begin{array}{l}0.25 \\
(11.41)\end{array}$ & $\begin{array}{l}0.057 \\
(0.448)\end{array}$ & 0.842 & $\begin{array}{l}4.42 \\
(25.478)\end{array}$ & 0.002 \\
\hline Ln_FDITourism & $\begin{array}{l}0.282 \\
(8.064)\end{array}$ & $\begin{array}{l}0.119 \\
(0.832)\end{array}$ & 0.641 & $\begin{array}{l}2.361 \\
(9.69)\end{array}$ & 0.046 \\
\hline
\end{tabular}

* Value in parenthesis shows constant term

\section{Concluding Remarks}

FDI is not yet a big contributor of economic growth in context of Nepal. But slowly, it is definitely creating its own stand in Nepalese economic scenario. On the basis of the major findings, it is quite evident that there is positive correlation between some major industrial FDI and GDP. Considering GDP as the dependent variable, FDI inflow in Manufacturing, Service and Tourism industries showed a significant relationship. Hence, it can be inferred that these three sectors play vital role in the economic growth of Nepal. Although very little investments are seen among construction and mining sectors, these are definitely some of the most lucrative sectors since there are lots of scopes for infrastructure development as Nepal still lags behind in terms of infrastructure and also the abundant resources present in Nepal are just waiting to be discovered. FDI should be lured in these sectors from where Nepalese economy can benefit more. It is important to attract domestic and foreign investment and increase employment opportunity for overall economic welfare. For this, policies should be made investment friendly which will attract the foreign investors in Nepal. More FDI flow means more economic growth in case of Nepal.

Nepal is still known as a virgin land yet to be explored. Even though resources are available, they are not being fully utilized. This brings huge opportunity for foreign investors. If investors are market seeker, then Nepal can be one of the best locations with two of the largest countries India and China as its neighbors. As the government has certified a number of business- and investment-friendly legislations like Foreign Investment and Technology Transfer Act (FITTA), Company Act, Industrial Enterprise Act, among others, in 2016-17, we can definitely see that the investment environment in Nepal is improving. But, policymakers should be cautious when implementing policies aimed at attracting 
FDI. Export oriented FDI should be given more priorities compared to domestic demand oriented in order to enhance growth.

Government should ensure conducive environment for investors. Government and policy makers should create a business climate that makes foreign investors feel that their capital is safe. Low tax rates or other tax incentives, protection of private property rights, access to loans and funding, and infrastructure that allow the fruits of capital investment to reach market, are a few of the incentives that countries may offer. Obtaining a good ranking in the World Bank's Doing Business report can also add up to the investment worthy image. So, Nepal should work on enhancing its image as the investment friendly and worthy country by implementing the existing legislations effectively.

\section{References}

Abbas, Q., Akbar, S., Nasir, A.S., Ullah, H.A. \& Naseemand, M.A. (2011). Impact of foreign direct investment on gross domestic product. Global Journal of Management and Business Research, 11(8), 35-40.

Acharya, S. (2013). A panel data analysis of foreign trade determinants of Nepal: Gravity model approach. NRB Economic Review, 25(1), 1-20.

Adhikari, R. (2013). Foreign direct investment in Nepal: Current status, prospects, challenges (No. 01/13) (SAWTEE Working Paper). South Asia Watch on Trade, Economics and Environment.

Aizhan, K. \& Makaevna, M. D. (2011). Impact of foreign direct investment on economic growth in Kazakhstan. International Conference on Sociality and Economics Development, IPEDR, 10.

Al-Eitan, G. (2013). A dynamic model for determining inward foreign direct investment in Jordan. Perth: School of Economics and Finance, Curtin University.

Alfaro, L., Chanda, A., Kalemli-Ozcan, S. \& Sayek, S. (2004). FDI and economic growth: The role of local financial markets. Journal of International Economics, 64(1), 89-112.

Alfaro, L., Chanda, A., Kalemli-Ozcan, S. \& Sayek, S. (2010). Does foreign direct investment promote growth? Exploring the role of financial markets on linkages, Journal of Development Economics, 91 (2), 242-256.

Basnett, Y., Henley, G., Howell, J., Jones, H., Lemma, A., \& Pandey, P. R. (2014). Structural economic transformation in Nepal. A Diagnostic Study Submitted to DFID Nepal. London: Overseas Development Institute, 203.

Bhattarai, B (2009). Economics of FDI in Nepal. My Republica. Retrive from http://archives.myrepublica.com/portal/index.php?action=news_details\&news id $=8448$ 
Phuyal \& Sunuwar: A Sectoral Analysis of Foreign Direct Investment on the Economic Growth of Nepal

Borensztein, E., Gregorio, J. De. \& Lee, W. (1997). How does foreign direct investment affect economic growth? Journal of International Economics, 45, $115-135$.

Carp, L. (2012).Analysis of the relationship between FDI and economic growth: Literature Review Study. The USV Annals of Economics and Public Administration, 12(1), 154-160.

Cristina, J. U. D. E., \& Levieuge, G. (2013). Growth effect of FDI in developing Economies: the Role of Institutional Quality(No. 2251). Orleans Economics Laboratory/Laboratoire d'Economie d'Orleans (LEO), University of Orleans.

De Mello, L.R. (1999). Foreign direct investment-led growth: Evidence from time series and panel data. Oxford Economic Papers, 51, 133-151.

Ghimire, R. (2012). Hydroelectricity project financing model in Nepal: Need for discussion. Journal of Economic Concern, 5, 1-9.

Hoang, T. T., Wiboonchutikula, P., \& Tubtimtong, B. (2010). Does foreign direct investment promote economic growth in Vietnam?. ASEAN Economic Bulletin, 295-311.

Hoang, T.T., Wiboonchutikula, P. \& Tubtimtong, B. (2010). Does foreign direct investment promote economic growth in Vietnam? ASEAN Economic Bulletin, 27 (3), 295-311.

Iram, S. \& Nishat, M. (2009).Sector level analysis of FDI-growth nexus: A case study of Pakistan. The Pakistan Development Review, 48(4), 875- 882.

Johnson, A. (2006). The effects of FDI inflows on host country economic growth, (Working paper No. 58). Centre for Excellence for Science and Innovation Studies, Royal Institute of Technology.

Majagaiya, K, P. (2010). A time series analysis of foreign direct investment and economic growth: A case study of Nepal. International Journal of Business and Management, 5(2), 144-148.

Nonnemberg, M.B. \& Cardoso de Mendonca, M.J. (2004).The determinants of foreign direct investment in developing countries. Rio de Janeiro: Instituto de Pesquisa Econômica Aplicada (IPEA).

Pant, B. (2010). Enhancing FDI flows to Nepal during the period of post-conflict transition and global recession. NRB Economic Review, 22, 19-39.

Ranjit, E. (2016). Pharmacy practice in Nepal. The Canadian Journal of Hospital Pharmacy, 69(6), 493-500. 